熱処理時間はガラス組成によって約 10 倍ほどちがう が, $\log t$ と $1 / T$ の勾配はいずれも同じである.これ らの関係から見掛けの分相の活性化エネルギーを求める と, $62 \mathrm{kcal} / \mathrm{mol}$ となる.このよらに分相速度はガラス 組成によって約 10 倍も異なるが活性化エネルギーは全 く同じで，分相機構が同じであることを意味している. 一方 R. Haul, E. Sucov らによってガラス中の酸素の 拡散の活性化エネルギーが求められているが，これらの 值は $30 \sim 70 \mathrm{kcal} / \mathrm{mol}$ のものが多い.これらのことから 分相過程の活性化エネルギーはガラス中の酸素の拡散の エネルギーに相当すると考えられる。

（2）充分分相したガラスの $1 \mathrm{~N}-\mathrm{H}_{2} \mathrm{SO}_{4} 100^{\circ} \mathrm{C}$ での $\mathrm{B}_{2} \mathrm{O}_{3} \cdot \mathrm{Na}_{2} \mathrm{O}$ 相の溶出速度は, ガラスの $\mathrm{SiO}_{2}$ 含有量と $\mathrm{Na}_{2} \mathrm{O} / \mathrm{B}_{2} \mathrm{O}_{3}$ 比によって約 10 倍変わり, $\mathrm{SiO}_{2}$ 含有量, $\mathrm{Na}_{2} \mathrm{O} / \mathrm{B}_{2} \mathrm{O}_{3}$ 比が大きいほど小さい。 $60^{\circ} \mathrm{C}, 80^{\circ} \mathrm{C}$,の 1 $\mathrm{N}-\mathrm{H}_{2} \mathrm{SO}_{4}$ について同様の実験を行なったが傾向は同じ で，いずれも $\log \delta_{M}{ }^{*}$ と $\sqrt{t}$ とは直線関係が成立っ た. また $\delta_{M} * / \sqrt{t}$ と $1 / T$ にも直線関係が成立し, そ の勾配はいずれのガラスについても同じである.これら の関係から溶出の活性化エネルギーを求めると約 6.5 $6.8 \mathrm{kcal} / \mathrm{mol}$ となる.これらのことから,ガラス組成に よって $\mathrm{B}_{2} \mathrm{O}_{3} \cdot \mathrm{Na}_{2} \mathrm{O}$ 相の溶出速度が約 10 倍異なるが溶 出機構はほとんだ同じで, また律速段階として酸に満た された $\mathrm{SiO}_{2}$ 多孔質層中での $\mathrm{B}_{2} \mathrm{O}_{3} \cdot \mathrm{Na}_{2} \mathrm{O}$ の拡散を考 えることができる. また溶出速度 $\log \delta_{M} * / \sqrt{t}$ とのガ ラスの $\mathrm{SiO}_{2}$ 含有量, $\mathrm{Na}_{2} \mathrm{O} / \mathrm{B}_{2} \mathrm{O}_{3}$ 比の間には大略直線
関係がある。

終りに, 終始御指導を頂いた当所第四部長桜井泰博士 に深く感謝します.

\section{文献}

1）江口清久, 田坂賢次, 垂水修二, 大工試季報 16, 147-156 (1965).

2) O.P. Moltschanowa, Steklo. i. Keramika 14, 57 (1957).

3) W. Rkatulla, W. Vogel, H. Wessel, Silicattechnik 9, 51-62 (1958).

4) M.E. Nordberg, J. Am. Ceram. Soc. 27, 299-305 (1944).

5) H.P. Hood, M.E. Nordberg, U.S.A. Pat. 2221709 (1968).

6）山本準之助, 岸井貫, 空協 59, 472-473 (1951).

7) 田村嘉行, 大工試報告 229 号 (1953).

8) K. Kühne, W. Skatulla, Silikattechnik 10, 105-119 (1959).

9) Y. Moori, K. Eguchi, Proc. 4th Intern. Congress on glass 273 (1956). 毛利良雄, 江口清久, 大工試季報 11, 108 (1960).

10) E.W. Sucov, D. Just, Gümbgen, Z. Elektrochem. 66, 636-41 (1962).

11) E.L. Williams, J. Am. Ceram. Soc. 48, 190-94 (1965).

13) W.D. Kingery, J.A. Lecron, Physics and chemistry of glass 1, 87 (1960).

14) W. Nernst, Z. Physik. chem. 47, 52 (1904). A.A. Noyes, W.R. Whitney, Z. Physik. chem. 23, 689 (1897).

15) A.R. Cooper, Advances in glass Technology 223 (1962).

16）江口清久，垂水修二，未発表

(3/5/1969 受付)

\title{
Optical Properties of Impurities-doped Hydrothermally Grown Zine Oxide
}

\author{
By \\ Noboru SAKAGAMI and Shuzo HASEGAWA \\ ( $\left.\begin{array}{c}\text { Research Institute of Electrical Communication, } \\ \text { Tohoku University, Sendai, Japan }\end{array}\right)$
}

\section{Introduction}

Zinc oxide single crystal is typical material in oxide semiconductors of $n$-type, and plays a subordinate role as a photoconductor and piezoelectrics. Recently there is an anticipation that $\mathrm{ZnO}$ single crystals can be used as the materials of transducer or accoustic amplifier elements, and that large sound single crystals of $\mathrm{ZnO}$ can be grown. In view of the anticipation, the hydrothermal method with an autoclave to controled impurities is more excellent than any other me- thod.

$\mathrm{ZnO}$ single crystals were grown hydrothermaly with $3 \sim 6 \mathrm{M} \mathrm{KOH}$ solutions in the autoclave, under nearly the same conditions as the temperature and the pressure used for quartz. $\mathrm{Li}, \mathrm{Cu}$, $\mathrm{Mn}$ and $\mathrm{Fe}$ were used as doped impurities, and in this study $\mathrm{Li}, \mathrm{Cu}$ and $\mathrm{Mn}$ were doped intentionally. Namely, 1 2 $\mathrm{M} \mathrm{LiOH}$ solvents were added to $\mathrm{KOH}$ solution as $\mathrm{Li}$ source and metallic copper powder (99.95\% pure, $1.0 \mathrm{wt} \%$ to nutrient) or $0.1 \mathrm{M} \mathrm{Cu}(\mathrm{OH})_{2}$ solvent was used with 
sintered $\mathrm{ZnO}$ or to $\mathrm{KOH}$ solution as $\mathrm{Cu}$ source, and $\mathrm{MnCO}_{3}$ reagent $(0.6 \sim 6.0 \mathrm{wt} \%$ to nutrient) was mixed with sintered $\mathrm{ZnO}$ as $\mathrm{Mn}$ source. While, the source of the Fe impurity was brought about by Fe dissolved from the inner wall of the autoclave, when the silver lining tube was sealed defectively in previous study ${ }^{1)}$. This report described the optical properties of those impuritiesdoped $\mathrm{ZnO}$ single crystals, from the view point of the impurity amount and crystal color, and of the absorption spectrum and photoconductive effect.

\section{Experiments}

The techniques of hydrothermal crystal growth were described in previous reports ${ }^{1 \sim 4}$. Grown crystals had prismatic and pyramidal shapes with size of about $10 \sim 25 \mathrm{~mm}$. Speciments for absorption and photoconductive experiments were sliced with diamond cutter, polished with SiC powder (800 mesh) and with $9 \mathrm{~N} \mathrm{KOH}$ solution at $90^{\circ} \mathrm{C}$ for a few minutes. The specimens were made up in thickness of $0.30 \pm 0.02 \mathrm{~mm}$.

To determine the contents of impurities, we used a few methods of a chemical analysis, of which were used a flame photometry for Li, a colorimetry for $\mathrm{Cu}$ and $\mathrm{Mn}$, and a gravimetric analysis for Fe. For the absorption measurements, a "Shimazu IV-50 A" automatic spectrophotometer and for the photoconductive measurements, a "Hitachi EPU-2 A" monochrometer were used. "The dark resistivity of $\mathrm{Li}-$ and $\mathrm{Cu}-\mathrm{ZnO}$ samples was about $10^{4} \sim 10^{8} \Omega$ at liquid nitrogen temperature, while the resistivity of $\mathrm{Mn}-$ and $\mathrm{Fe}-\mathrm{ZnO}$ was about $10^{1} \sim 10^{2} \Omega$ at the same temperature. The photoconductive effects were carried out supplying a constant voltage of $30 \mathrm{~V}$ by an usual DC method.

\section{Results and discussion}

\subsection{Impurity amount and crystal color}

The impurity contents of the respective sample in this study were as follows: $\mathrm{Li}$ contents, $3 \sim 5$ ppm; $\mathrm{Cu}$ contents, $10^{2} \mathrm{ppm}$; Mn contents, $0.2 \sim$ $1.2 \mathrm{wt} \% ; \mathrm{Fe}$ contents, $0.5 \mathrm{wt} \%$. Under the growth conditions of $\mathrm{Li}-$ and $\mathrm{Cu}-\mathrm{ZnO}$, even if the concentration of impurity source was increased,

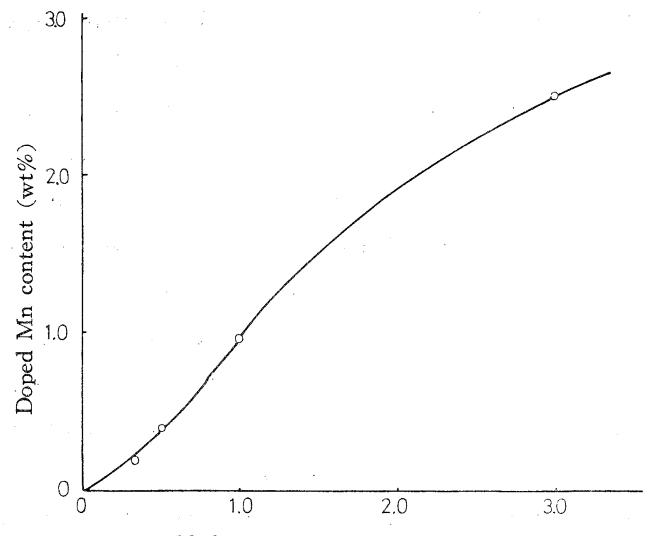

Added Mn concentration (wt $\%$ )

Fig. 1. Doped Mn contents in hydrothermally grown $\mathrm{ZnO}$ vs. added $\mathrm{Mn}$ contents in nutrient.

the doped-impurity in grown crystal was little increased quantatively. But in the cases of $\mathrm{Mn}$ and $\mathrm{Fe}-\mathrm{ZnO}$, the contents of the doped-impurity were increased in propotion to the concentration on the impurity source. Fig. 1 shows the relation between the concentration of the impurity source and the contents of the doped-impurity in grown crystals, in the case of $\mathrm{Mn}-\mathrm{ZnO}$. This fact was corresponded with a color of the grown crystals, e.g., in the case of the smallest $\mathrm{Li}$-doped $\mathrm{ZnO}$, it was found hardly that the impurity, $\mathrm{Li}$ had influence on the color of the grown crystals. Althogh the color of $\mathrm{Li}-\mathrm{ZnO}$ turned almost yellow, this color was caused possibly by having color centers under interstitial excess of $\mathrm{Zn}$ in hydrothermally grown $\mathrm{ZnO}$, because the growth environment was brought to reducing condition ${ }^{4}$. $\mathrm{Cu}$ contents in $\mathrm{Cu}-\mathrm{ZnO}$ were a little larger than $\mathrm{Li}$ in $\mathrm{Li}-\mathrm{ZnO}$, but the influence on the color was shown similarly with $\mathrm{Li}-\mathrm{ZnO}$.

In the case of $\mathrm{Mn}-\mathrm{ZnO}$ or $\mathrm{Fe}-\mathrm{ZnO}$, however, according as increasing each doped amount of impurity the change of the crystal color could be distinguished. The color of $\mathrm{Mn}-\mathrm{ZnO}$ chanegd from reddish orange to deep red with increasing $\mathrm{Mn}$ contents from 0.2 to $1.2 \mathrm{wt} \%$. The color of a natural $\mathrm{ZnO}$ crystal (zincite) turns to a similar red and changes with increasing or decreasing $\mathrm{Mn}$ contents ${ }^{5}$.

Table 1. Summary of impurities-doped $\mathrm{ZnO}$ crystals. $(x=0 \sim 9)$

\begin{tabular}{|c|c|c|c|c|c|c|}
\hline \multirow[b]{2}{*}{ Properties } & \multirow{2}{*}{$\mathrm{Li}-\mathrm{ZnO}$} & \multirow{2}{*}{$\mathrm{Cu}-\mathrm{ZnO}$} & \multirow{2}{*}{$\mathrm{Fe}-\mathrm{ZnO}$} & \multicolumn{3}{|c|}{$\mathrm{Mn}-\mathrm{ZnO}$} \\
\hline & & & & 1 & 2 & 3 \\
\hline $\begin{array}{l}\text { Crystal color } \\
\text { Crystal habit }\end{array}$ & $\begin{array}{l}\text { Pale yellow } \\
\text { pyramidal }\end{array}$ & $\begin{array}{c}\text { yellow } \\
\text { prismatic }\end{array}$ & $\begin{array}{l}\text { dark green } \\
\text { prismatic }\end{array}$ & reddish orange & $\begin{array}{c}\text { red } \\
\text { prismatic }\end{array}$ & deep red \\
\hline Impurity conc. & $3 \sim 5 \mathrm{ppm}$ & $10^{2} \mathrm{ppm}$ & $0.5 x \%$ & $0.1 x \%$ & $0.4 x \%$ & $1.2 x \%$ \\
\hline Conductivity $\left(\mho \mathrm{cm}^{-1}\right)$ & $10^{-5}$ & $10^{-2} \sim 10^{\circ}$ & $10^{2}$ & & $10^{2} \sim 10^{3}$ & \\
\hline Absorption of impurity $(\mathrm{m} \mu)$ & 398 & 440 & 490 & 510 & 530 & 550 \\
\hline Photoconductive effect & $\bigcirc$ & 0 & $?$ & & $?$ & \\
\hline
\end{tabular}


The one of $\mathrm{Fe}-\mathrm{ZnO}$ changed from green to dark green with $\mathrm{Fe}$ contents of $0.1 \sim 1 . x(x=0 \sim$ 9) wt $\%$. Those results are shown in Table 1.

For $\mathrm{Li}-$ and $\mathrm{Cu}-\mathrm{ZnO}$, it was investigated previously by the electrical properties how each impurity was doped in the crystal $^{4}$. Since the crystals are grown with reduced environment, if the added impurity is ionized into the growth solution, this valency may be harmonized with the

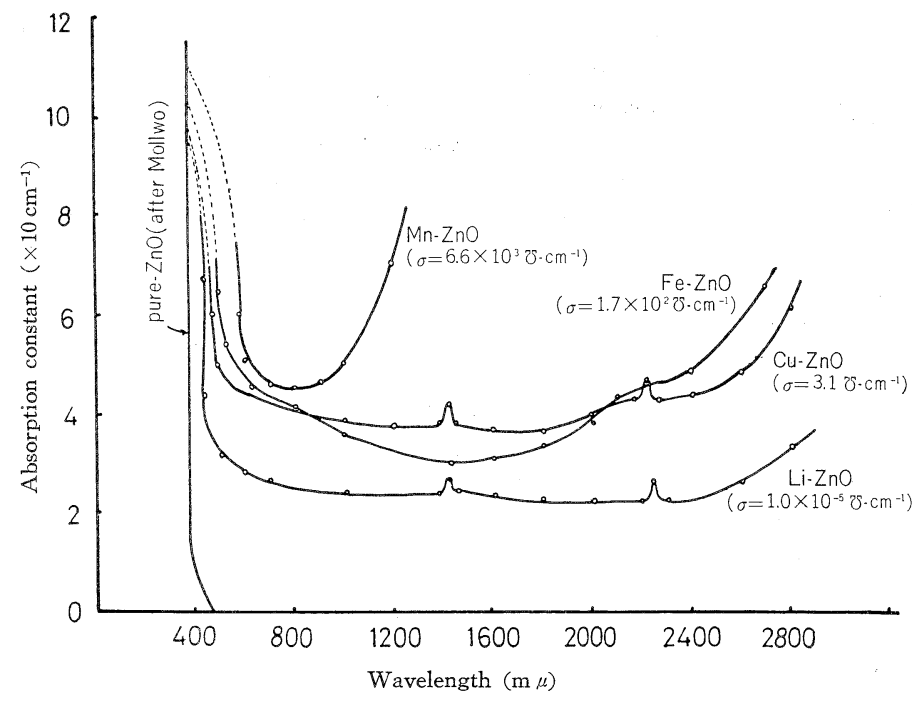

Fig. 2. Absorption spectra of verious impurities-doped $\mathrm{ZnO}$ crystals (sample, plate $3 \times 10^{-2} \mathrm{~cm}$ thick). tive effect smallest number of possible and variable valency. Therefore, $\mathrm{Mn}$ in $\mathrm{Mn}-\mathrm{ZnO}$ and $\mathrm{Fe}$ in $\mathrm{Fe}-\mathrm{ZnO}^{*}$ possibly become $\mathrm{Mn}^{++}$and $\mathrm{Fe}^{++}$.

3.2 Absorption spectrum and photoconduc-

The absorption spectra of a pure $\mathrm{ZnO}, \mathrm{Zn}$ - and $\mathrm{Cu}-\mathrm{ZnO}$ crystals obtained by vapor phase method. was described by Mollow ${ }^{6}$. Fig. 2 shows an illustration of the absorption spectra of impurities: doped hydrothermally grown $\mathrm{ZnO}$. In all cases, it seem that the rise of the absorption constant in transition from the visible to the infrared is: changed. For $\mathrm{Mn}-$ and $\mathrm{Fe}-\mathrm{ZnO}$, this. phenomenon was distinguished especially. As the absorption constant was very small, of course, the curves: were not indicated the fundamental absorption edge of $\mathrm{ZnO}$ crystal. Such the mesurements had been made only on thin layers obtained by vapor growth. In Fig. 2, it was thought generally that the steep rise of the absorption constant at the short wavelengths was indicated by the proper absorption of each impurity. Because, $\mathrm{Li}$-and $\mathrm{Cu}-\mathrm{ZnO}$ samples showed the photoconductive effects at each wavelength (Fig. 3). In other hand, although $\mathrm{Mn}$ - and $\mathrm{Fe}-\mathrm{ZnO}$ could not: yet measure these effects due to the low dark resistivity of samples, the absorptions. were believed to be shown by one of the impurity from the color of crystals. And that the absorption of this color was shifted toward longer:

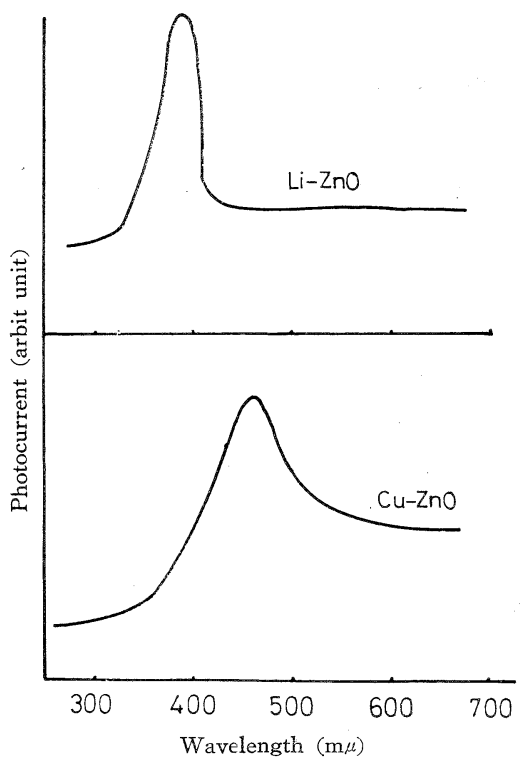

Fig. 3. Photoconductive effects of $\mathrm{Li}-\mathrm{ZnO}$ and $\mathrm{Cu}-\mathrm{ZnO}$ crystals. The wavelength of photoconductive effect is coupled with the steep rising position of the absorption constant at short wavelengths.

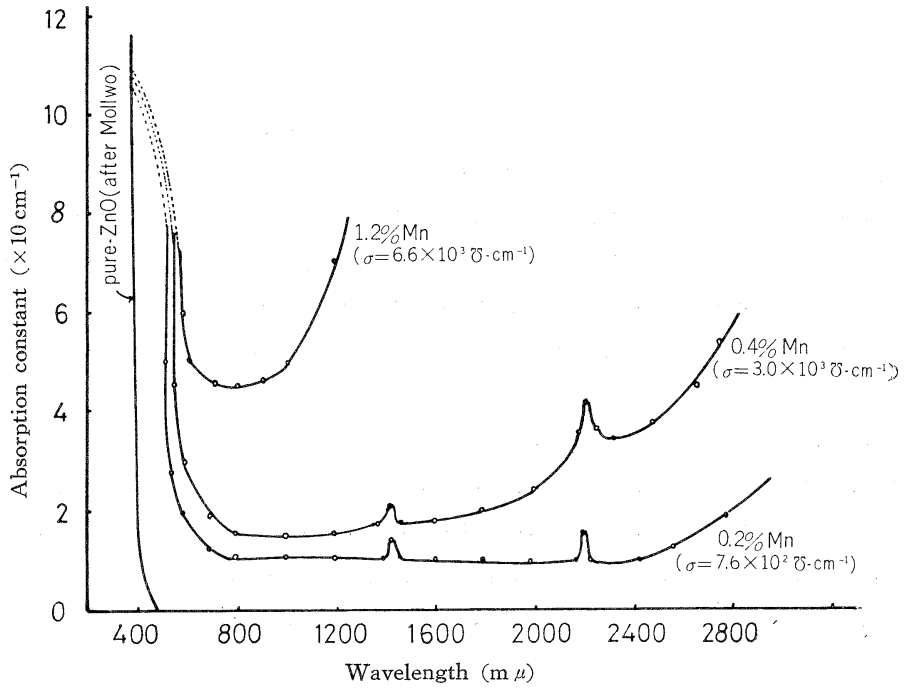

Fig. 4. Absorption spectra of $\mathrm{Mn}-\mathrm{ZnO}$ with increasing. Mn contents. 


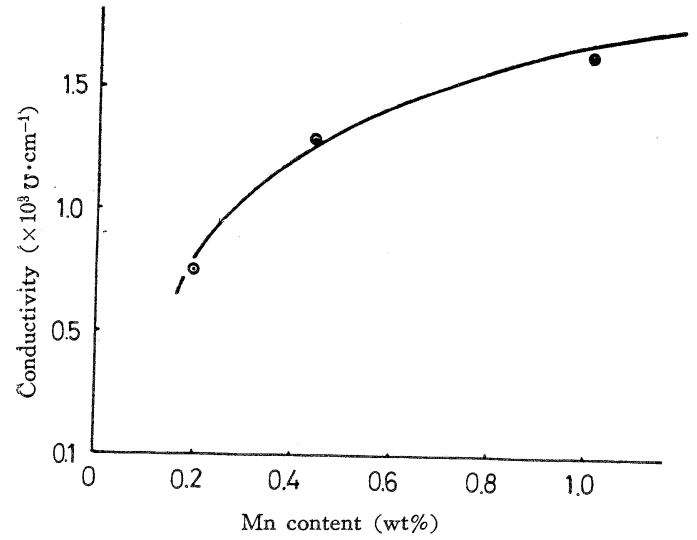

Fig. 5. Conductivity vs. Mn contents in $\mathrm{Mn}-\mathrm{ZnO}$ crystal.

wavelengths with increasing doped impurity, e.g., $\mathrm{Mn}$ (Fig. 4). In all cases except $\mathrm{Fe}-\mathrm{ZnO}$ and 1.2 $\% \mathrm{Mn}-\mathrm{ZnO}$, the obvious peaks which could be regard as a proper of $\mathrm{ZnO}$ crystal observed at the positions $\lambda=1420 \mathrm{~m} \mu$ and $\lambda=2240 \mathrm{~m} \mu$ (Fig. 2 and Fig. 4). Up to present time such the absorption peaks on the single crystal obtained by vapor growth were found only in more longer wavelength region, i.e., at $6700 \mathrm{~m} \mu$ and $8100 \mathrm{~m} \mu$, and on the $\mathrm{ZnO}$ powder or sintered $\mathrm{ZnO}$ such numerous ones were found in further long wavelength region ${ }^{6}$. But any positive interpretation between them have not yet been obtained.

Mollow $^{6}$ has shown that the increase of color centers may be concerned with the increase of the conductivity. For $\mathrm{Mn}-\mathrm{ZnO}$ this relation is given very clearly in Fig. 4 and Fig. 5. If $\mathrm{Fe}^{++}$ and $\mathrm{Mn}^{++}$with excess of $\mathrm{Zn}$ take the interstitial positions, they bring about the characteristic color centers and that form the donor levels. Therefore, according to increase the dopant, $\mathrm{Mn}^{++}$or $\mathrm{Fe}^{++}$, the color is concentrated gradually and the conductivity become of high. Since those donor impurities very decreased the dark resistivity of the crystal, in view of sensitization, it has need of a suitable compensative impurity, e.g., Li. A study of the compensators is presently under way.

\section{Acknowledgement}

The authers wish to express their sincere thanks to Dr. H. Konno and Mr. T. Koda for their valuable helps carrying out the experiments.

\section{References}

1) G. Ohara, S. Hasegawa and N. Sakagami, The Record of Elect. and Comm. Eng. Convesazione Tohoku Univ. 35, 121-28 (1966).

2) R.A. Laudise, E.D. Kolb and A.J. Caporaso, $J$. Am. Ceram. Soc. 47, 9-12 (1964).

3) N. Sakagami, S. Hasegawa and G. Ohara, The Record of Elect. and Comm. Eng. Conversazione Tohoku Univ. 36, 83-87 (1967).

4) N. Sakagami, S. Hasegawa and G. Ohara, Sci. Rep. RITU, B-(Elect. Comm.) 19, 199-213 (1967).

5) Dana's System of mineralogy Vol. 1, John Wiley and Sons (1944).

6) E. Mollow and G. Heiland, Solid State Physics 8, 216-36 (1959).

[Received March 6, 1969]

\section{不純物ドープ水熱育成酸化亜鉊の光学的性質}

\section{坂上登・長谷川修三 （東北大学電気通信研究所）}

酸化带鉛単結晶の圧電半導体としての性質を利用し て,トランスジューサー, 超音波増幅素子としての応用 が考えられている.水熱条件下で得られる $\mathrm{ZnO}$ はその 雾囲気が還元性であるために，不純物無添加の場合は過 剩 $Z n$ が格子間位置を占めて暗抵抗を低下させる.そこ で，筆者らは，その補償のために， $\mathrm{Li}^{+}, \mathrm{Cu}^{+}$などを不 純物として添加し, また, 光学増感的な立場加 $\mathrm{Mn}^{++}$ などの不純物添加を試みて，その波長吸収特性やドープ 量, 色調などの光学的な検討を行なった。

$\mathrm{Li}-\mathrm{ZnO}$; 結晶中にドープされる $\mathrm{Li}$ 量は数 $\mathrm{ppm} \sim 10$ ppm までで, この範囲の濃度変化では結晶の色調, 波 長吸収には影著な変化は認められない。しかし, 電気抵
抗の変化は著しい(4). Li 吸収の位置は $398 \mathrm{~m} \mu$ であり, 光電導もこの近くに現われる.

$\mathrm{Cu}-\mathrm{ZnO} ; 10^{2} \mathrm{ppm}$ オーダーの量がドープされ, $\mathrm{Cu}$ 吸収と思われる波長は $440 \mathrm{~m} \mu$ で光電導効果 と一致す る.

$\mathrm{Fe}-\mathrm{ZnO}, \mathrm{Mn}-\mathrm{ZnO}$; 共にドープ量の変化により，色 調, 吸収の位置の変化が著しく, 不純物量を増加して行 くと色は濃くなり，吸収の位置も長波長側にずれ，電気 抵抗の減少をみる。 Mn 量の少ない $\mathrm{Li}-\mathrm{Mn}-\mathrm{ZnO}$ につ いて, 光学増感的な意味で目下検討中である.

(3/6/1969 受付) 